\title{
Determinants of Value Creation of GCC Firms - An Application of PLS SEM Model
}

\author{
Rajesh Kumar B \\ Associate Professor, Finance \\ Institute of Management Technology, Dubai Academic City \\ Dubai, UAE \\ E-mail: rajesh@imtdubai.ac.ae
}

Received: Oct. 17, 2014 Accepted: Dec 30, $2014 \quad$ Published:June 1, 2015

doi:10.5296/ajfa.v7i1.6464 URL: http://dx.doi.org/10.5296/ajfa.v7i1.6464

\begin{abstract}
Value creation for a firm is a function of identifying and managing value drivers. This study aims to understand the drivers of value creation for GCC listed firms. The paper proposes a model for value creation through the application of Partial Least Square Structural Equation Modeling (PLS-SEM).The model proposes value creation of a firm as a function of critical drivers like size of firm, dividend policy, investment policy, capital structure and risk characteristics. Higher the leverage for the firm, lesser will be the value creation for the firm. Investors are skeptical about whether firms with high leverage would create value. Firm size is negatively related to value creation.
\end{abstract}

Keywords: Value Creation, PLS SEM, Path Diagram, Bootstrapping, Reflective Measurement models, Heterotrait-monotrait ratio, Blind Folding. 


\section{Introduction}

The determinants of value creation can be categorized in terms of growth, size, efficiency, capital structure and profitability drivers. Value creation for a firm is a function of identifying and managing value drivers which have the greatest impact on value creation. A focused approach would enable management to transform the goals of value creation into specific actions. Value driver analysis is an important tool in strategic planning analysis. Organizations which create long term value in terms of shareholder wealth are expected to create value for all stakeholders. From the perspective of economist's value viewpoint, value is created when revenues exceed all costs. Value is created when management generates revenues over and above the economic costs incurred to generate revenues. The costs come from sources like employee wages and benefits, material, supplies, economic depreciation of physical assets, taxes and opportunity cost of capital. Shareholders expect management to generate value over and above the costs of resources consumed which includes the cost of using capital. Shareholders require an adequate level of return for the risk they take in. Stock prices reflect investors' expectations about future cash flows. Wealth for shareholders will be created only if firms undertake investment decisions which have a positive net present value. Value creation is used in the perspective of value derived from accounting based information. Wealth creation is based on stock market information.

Shareholders' wealth maximization is theoretically logical and operationally feasible normative goal for guiding the financial decision making. From the shareholders' point of view, the wealth created by a company through its actions is reflected in the market value of the company's shares.

Profitability and growth are basically considered as the major determinants of firm value. Corporate strategies can be assessed on the basis of their expected effect on profitability, growth and firm value. The value based planning models suggests that management of a firm aims to create shareholder wealth by maximizing market value of the equity thereby creating excess value over the book value of the firm. A firm's management must focus on strategies that creates excess value attributed to market value (MV) compared to the book value (BV) of equity. A firm's management creates value for shareholders if $\mathrm{MV}>\mathrm{BV}$, destroys value if $\mathrm{MV}<\mathrm{BV}$ and maintains value if $\mathrm{MV}=\mathrm{BV}$. Many researchers have focused on establishing the linkage between the strategic position of a company and its financial performance.

Identifying and selecting strategies that create value for shareholders is a major challenge facing management in the modern era. The identification of financial factors which have the highest impact on value creation in a business can facilitate establishment of criteria for appropriate strategy selection in that direction. The ability of a firm to create value by distributing cash flows to its stakeholders depend on its ability for cash generation from its operating activities and access of additional funds through external financing. The two basic sources of external financing are debt and equity financing. A company's ability to borrow today is based on projections of its future cash flow generation.

The shareholder returns basically depends on prices, costs, investments, volume of products sold and riskiness of firms in an industry. The variables representing these factors can be 
considered as determinants of shareholder value. Working capital and fixed capital investment are the two components of investment value drivers. Management's investment choices and financial policy are also value drivers in the context of riskiness of cash flows for the company. Scale economies for firms in purchasing, manufacturing, distribution and research can generate value drivers in operating margin, working capital investment and fixed capital investment. The link between value chains and value drivers as reflected by sales growth rate, operating profit margin, income tax rate, working capital investment, fixed capital investment and cost of capital are basic building blocks of shareholder value creation.

Total risk is the combination of business risk and financial risk. Business risk is the uncertainty inherent in the business operations. Financial risk arises for shareholders on account of the increased leverage due to additional debt in the capital structure. The financial leverage increases would lead to increased variability of cash flows since fixed interest payment is bound to increase. Hence shareholders expect higher returns for highly leveraged firms. Strategies which increase business risk can increase systematic risk which is measured by betacoefficient. Investors expect higher rate of return as the systematic risk of the firm increases.

Earnings is considered an important variable which affects the market value of equity shares. The investment decisions aimed at expansion of scale of operations ultimately is focused on earnings generation. Hence earnings enhancement could affect market value of a company. Many studies have considered measures of market value of equity in excess of book value like Tobin q, market to book value, price to earnings ratio or price to sales ratio as the variable representing value created in a firm. Studies have also highlighted the positive contribution of research and development (R\&D) investments to economic growth, productivity and profitability.

\section{Objective of the Study}

The basic objective of the paper is to examine the determinants of value creation in terms of drivers.In other words study aims to understand the drivers of value creation for GCC listed firms.

\section{Review of Literature}

The study by Sam Ben et al (2002) uses random probit model estimation procedure to estimate the determinants of value creation among companies listed in Tunisia stock exchange. The study finds that probability of creating future value is significantly correlated with profitability. The study also finds that value creation is affected by industry patterns, size and nature of property. The linkage between strategic position of a company and its financial performance have been advocated by studies of De Bodinat (1978), Pene (1983), Degos et al (1988) etc. The study by Rappaport (1987) suggests the determinants of value creation as growth rate, operating profit margin, income tax rate, working capital investment, fixed capital investment, cost of capital and value growth duration. Caby et al (1996) based on a sample of French companies find that the determinants of value creation are variables based on profitability, activity, financial policy, investment policy and dividend policy. The 
study by Varaiya (1987) highlights the significance of Return on Equity (ROE) as a signal of profitable investment. The results of this study indicate that profitability and growth do influence shareholder value and the market to book value of equity ratio, Tobin's q ratio are theoretically and empirically equivalent measures of value creation. The studies by Ross (1977); Bhattacharya (1979), Hakansson (1982), Miller et al (1985) suggests that dividend payment signals the market about the higher cash flow generation potential of firms. The choice of debt level is a signal of firm quality (Leland 1977, Ross 1977, Myers 1977). Rappaport (1986) suggests that profitability is an important determinant of value creation. Profitability improvement can result from economies of scale, cost reducing linkages with suppliers and channels.

Banz (1981) advocates size effects (measured by market capitalization) as a significant determinant of average returns provided by market beta. This study finds that average returns on small size ( low market capitalization) stocks are too high given their beta estimates and average returns on large size (high market capitalization) stocks are low. Bhandari (1988) documents positive relationship between leverage and average returns. Studies by Stattman (1980) and Rosenberg et al (1985) finds that average returns on stocks are positively related to the ratio of firm's book value of equity to market value of equity. The study by Chan et al (1991) finds that the ratio of book value to market value of equity is a significant determinant in explaining the cross section of average returns on Japanese stocks. Chen et al (1991) postulate that the earning prospects of firms are associated with a risk factor in returns. Firms with low stock prices and high ratio of book to market equity which are characterized having poor prospects by market are considered risky and have higher expected stock returns than firms with strong prospects.

Basu (1983) suggests that the earning-price ratios (E/P) is a variable that explain the cross section of average returns on US stocks which includes size and market beta variables. The studies by Black et al (1972) and Fama et al (1976) find positive relation between average stock returns and beta. The study by Fama and French (1992) suggests that size (measured by market value of equity) and book to market equity are important determinants which reflect powerful characterization of the cross section of average stock returns during the period 1963-1990. The main results of the Fama and French (1992) study indicates that for the 1963-1990 period, size and book to market equity capture the cross sectional variation in average stock returns associated with size, E/P, book to market equity and leverage. It can be stated that if the stocks are priced rationally, systematic differences in average returns can be attributed to differences in risk. In the perspective of rational pricing, the variables size measured by the total market capitalization (price multiplied by number of shares) and $\mathrm{BE} / \mathrm{ME}$ can be considered as proxy variables to sensitivity to common risk factors in returns.

Fama and French (1995) study the behavior of stock prices in relation to size and book to market equity (BE/ME), which reflects the behavior of earnings. Specifically the study explores whether the behavior of stock prices in relation to size and book to market equity is consistent with the behavior of earnings. In the context of rational pricing, the study indicates that high $\mathrm{BE} / \mathrm{ME}$ signals persistent poor earnings and low BE/ME signals strong earnings. $\mathrm{A}$ low stock price relative to book value (high $\mathrm{BE} / \mathrm{ME}$ ) signals sustained lower earnings on 
book equity. In summary low BE/ME (high stock price relative to book value) is typical of firms with high average returns on capital (growth stocks), whereas high BE/ME is typical of firms that are relatively distressed. Fama and French (1995) also suggest that size is related to profitability. Controlling for BE/ME, small stocks tend to have lower earnings on book equity than do big stocks. Penmann (1991) suggests that low book to market equity firms remain more profitable than high $\mathrm{BE} / \mathrm{ME}$ firms.

Firms with higher required equity returns will have higher book to market ratios. This prediction is consistent with the positive relation between average stock return and BE/ME observed by Fama and French $(1992,1995)$. Fama and French (1995) predicts that high $\mathrm{BE} / \mathrm{ME}$ should be associated with a persistently low ratio of earnings to book equity, while low BE/ME should be persistently associated with strong earnings to book value of equity. In other words low $\mathrm{BE} / \mathrm{ME}$ stocks are on average more profitable than high $\mathrm{BE} / \mathrm{ME}$ stocks.

Debt equity ratio (DER) is used as a variable to explain the expected common stock returns. An increase in debt equity ratio of a firm increases the risk of its common equity. Cross sectionally the common equity of a firm with higher debt equity ratio always have higher risk since the firm level risk may vary, DER is expected to be positively correlated to the risks of common equity across firms (Bhandari 1988). Beta is based on a market proxy and calculated for a period.

The financial leverage hypothesis suggests that increase in debt is a signal to the market that the firm's prospects have improved. The dividend payout hypothesis suggests that value creation is a function of the dividend payout of companies. Higher the dividend payout more is the value creation for the company. Ross (1977) suggests that companies that increase dividend payout signal to the market that it has the potential to generate future cash flows to meet future dividends. The value of a company is expected to increase on account of dividend payment as it signals to the market that the firm is expected to have higher cash flows. The profitability hypothesis suggests that higher the profits generated by firms, greater would be the value creation.

The study by Gamba and Triantis (2008) develop a model that endogenizes dynamic financing, investment and cash retention/payout policies in order to analyze the financial flexibility on firm value. The study demonstrate that value of financing flexibility depends on the costs of external financing, the level of corporate and personal tax, the firm's growth potential.

Michael et al (2001) suggests integration of entrepreneurial and strategic thinking for value creation in entrepreneurial firms. The paper by Amhud (2002) shows that over time, expected market illiquidity positively affects ex ante stock excess return, suggesting that expected stock excess return partly represents an illiquidity premium. Severine et al (2004) examines the determinants of stock returns in a small open economy using an APT framework and finds that statistical factors yield a better representation of the determinants of stock returns than macroeconomic variables. Boyer et al (2007) find that the return of Canadian energy stock is positively associated with the Canadian stock market return, with appreciations of crude oil and natural gas prices, with growth in internal cash flows and proven reserves, and 


\section{Macrothink}

Asian Journal of Finance \& Accounting

ISSN 1946-052X 2015, Vol. 7, No. 1

negatively with interest rates. The study by Fang L et al (2009) find that stocks with no media coverage earn higher returns than stocks with high media coverage even after controlling for well-known risk factors.

\section{Methodology}

\subsection{Model Discussion}

The proposed model for value creation is framed with respect to latent constructs as given in the diagrammatic design below. It is assumed that value creation is a function of critical variables of size of the firm, dividend policy of the firm, investment decisions, capital structure and risk characteristics of the firm. It is hypothesized that investment decisions would lead to growth which in turn would lead to profitability and results in value creation.



Figure 1. Initial Path Diagram for Value Creation

The relationship between the constructs is based on the direction of arrows. The latent constructs of Dividend Policy (DIVPO), Firm Size, Growth, Investment Decision (INVESTDECI), Risk, Capital Structure are designed with reflective indicators. The final latent construct of value creation is designed with formative indicators of average stock returns, earnings to book value of equity and ratio of market value to book value of the firm. The description of the reflective and formative indicators is provided in the table below. 


\section{Ml Macrothink}

Table 1. Reflective and Formative indicator definitions

\begin{tabular}{|c|c|}
\hline Variables & Definitions \\
\hline $\mathrm{MVt} / \mathrm{BVt}$ & Market Value of Firm / Book Value of Firm in year $t$ \\
\hline LNSA & Natural Log of Average Revenue in $t-1$ to $t-3$ \\
\hline Dividend Payout (DPO) & Total Dividends / Total Earnings in t -1 to $\mathrm{t}-3$ \\
\hline LNTA & Natural $\log$ of Total Assets in $\mathrm{t}-1$ to $\mathrm{t}-3$ \\
\hline Lev(Leverage) & Total debt / Total Equity in $\mathrm{t}-1$ to $\mathrm{t}-3$ \\
\hline LNME & Natural $\log$ of Market Equity in $\mathrm{t}-1$ \\
\hline Return on Equity (ROE) & Net Income / Total Equity in t-1 to $\mathrm{t}-3$ \\
\hline Return on Assets (ROA) & Net Income / Total Assets in t-1 to t-3 \\
\hline $\mathrm{CAPEX} / \mathrm{TA}$ & Capital expenditure / Total Assets in t-1 to t-3 \\
\hline $\mathrm{WC} / \mathrm{TA}$ & Working capital / Total Assets in $\mathrm{t}-1$ to $\mathrm{t}-3$ \\
\hline SG & Sales Growth rate in $\mathrm{t}-1$ to $\mathrm{t}-3$ \\
\hline EG & Earnings Growth rate in $\mathrm{t}-1$ to $\mathrm{t}-3$ \\
\hline Earnings / Price (E/P) & $\begin{array}{l}\text { Total Earnings / Market Capitalization in } \mathrm{t}-1 \text { to } \mathrm{t}-3 \text {. Market } \\
\text { Capitalization is price multiplied by number of shares. }\end{array}$ \\
\hline Return & Average monthly returns in July of year $t$ to June of year $t+1$. \\
\hline Beta & $\begin{array}{l}\text { Measures the systematic risk of the stock. Beta is found out by } \\
\text { regressing stock returns for a stock on respective market indices } \\
\text { returns based on one year of data. Beta is calculated for one } \\
\text { year period t- } 1 \text {. }\end{array}$ \\
\hline Div Yield & Dividend per Share / Market Price per Share in t-1 to t-3. \\
\hline Et / BEt-1 & Total Earnings in $\mathrm{t}$ / Book value of Equity in $\mathrm{t}-1$ \\
\hline
\end{tabular}

The formative indicator variables of market value of firm to book value of firm, average stock returns and earnings were based on the year 2012. One of the formative indicator for final latent construct of value creation was Et / BEt-1 where Et was in the year 2012 and. BEt-1 was based in the previous year, The average accounting data for the year's t- 1 to $t-3$ is matched with the average monthly returns for July of year $t$ to June of year $t+1$. The values for variables of size, dividend payout, profitability are average values for period t-1 to t-3 (2009-2011). The financial data was collected from the balance sheets of the firms. The stock market data was collected from the seven stock exchange websites.

\subsection{Sample Selection}

For the empirical modelling part, we selected eight companies with highest average market capitalization from Saudi Tadawul, and seven companies each from other six stock markets -Dubai Financial Markets, Abu Dhabi Securities Exchange, Muscat Securities Market, Qatar Exchange and Kuwait Stock Exchange The average market capitalization was based on five years during the period 2009-2013. The value of average market capitalization was calculated 
in US dollars. All financial variables in terms of value were converted to US dollars based on the exchange rate of US dollar vis a vis GCC currencies ${ }^{1}$.

Table 2. Sample segregation

\begin{tabular}{ll}
\hline Sector & Number of Companies \\
\hline Banking & 22 \\
Industrial & 6 \\
Telecommunication \& IT & 5 \\
Investment and Financials & 5 \\
Petrochemical and energy & 3 \\
utilities & \\
Real Estate and & 3 \\
Construction & \\
Consumer services & 3 \\
Insurance & 2 \\
Transport & 1 \\
Total & 50 \\
\hline
\end{tabular}

The following table gives the descriptive statistics for 50 sample companies based on five yearly average values. The table below e gives the descriptive statistics of the sample firms involved in the empirical study. The descriptive statistics of variables like total assets, revenues, cash flows and net profit are given in the table. The average, mean, standard deviation, the maximum value and minimum value of the sample statistics are given. The descriptive statistics are for 50 sample companies based on five yearly average values.

The average total assets and revenues of the sample firms amounted to $\$ 23.65$ billion and $\$ 3.2$ billion respectively. The standard deviations for the total assets and revenues were 28.59 and 6.47 respectively. Hence the variability in asset size and revenues were higher in the sample firms. The analysis for the maximum and minimum value for assets and revenues suggests huge difference in values. The sample firms had an average cash flow and net profit of $\$ 8.7$ billion and $\$ 0.416$ billion respectively. The standard deviation for cash flow and net profit were $\$ 46.82$ billion and $\$ 0.521$ billion respectively.

Table 3. Descriptive Statistics (Values in millions of dollars)

\begin{tabular}{lllll}
\hline Variables & Average & Standard deviation & Maximum & Minimum \\
\hline Total Assets & 23656.39 & 28599.43 & 140216.56 & 463.45 \\
Revenues & 3200.91 & 6472.93 & 42266.60 & 31.68 \\
Cash Flow & 8703.81 & 46824.72 & 330799.50 & -68.47 \\
Net Profit & 416.06 & 521.15 & 2111.88 & -413.85 \\
\hline
\end{tabular}

\footnotetext{
${ }^{1}$ UUSD=3.67AED; 3.75 Saudi Riyal; 3.64 Qatari riyal; 0.28 Kuwaiti Dinar; 0.38 Bahrani dinar ; 0.38 Omani rial.
} 
The following table provides the cross sectional statistics of the reflective and formative indicators. Thecross-sectional statistics are for averages, standard deviation, maximum and minimum values for the sample firms. The variables indicate growth, earnings, leverage, profitability and risk measures. Size is measured by book value of total assets and market value of equity. Risk is measured by beta.

Table 4. Cross sectional variable statistics

\begin{tabular}{ccccc}
\hline Variables & Average & $\begin{array}{c}\text { Standard } \\
\text { Deviation }\end{array}$ & Maximum & Minimum \\
\hline MV / BV & 1.05 & 0.50 & 2.36 & 0.15 \\
Log (Sales) & 6.90 & 1.74 & 10.58 & 0.0000 \\
Earnings & & & & \\
Growth & 1.80 & 9.53 & 66.70 & -4.6800 \\
Log (Total & & & & \\
Assets) & 9.09 & 1.91 & 12.02 & 0.0000 \\
Dividend & & & & \\
Payout & 0.38 & 0.35 & 1.70 & 0.0000 \\
Leverage & 3.61 & 3.12 & 12.91 & 0.0000 \\
ROE & 1.60 & 8.6 & 46.8 & -8.3 \\
ROA & -0.27 & 2.14 & 0.17 & -15.16 \\
CAPEX/TA & 0.0040 & 0.06 & 0.26 & 0.0000 \\
WC/TA & -0.28 & 0.68 & 1.06 & -4.3 \\
Sales & & & & \\
Growth & 0.12 & 0.28 & 1.23 & -0.23 \\
E/P & 0.98 & 1.67 & 6.1200 & -1.32 \\
Return & -0.0009 & 0.0322 & 0.12 & -0.11 \\
Beta & 0.94 & 0.61 & 2.64 & 0.0000 \\
ln (ME) & 9.3 & 1.5705 & 11.74 & 4.3 \\
$\ln$ BV/MV & 0.08 & 0.56 & 1.86 & -0.85 \\
Dividend & & & & \\
Yield & 0.09 & 0.40 & 2.75 & 0.0000 \\
\hline
\end{tabular}

The partial least squares structural equations modeling (PLS-SEM) was used to test the determinants of value creation in the GCC firms. The Structural Equation Modelling procedure can be done in two ways, namely covariance based structural equation modeling (CB-SEM) and partial least squares modeling (PLS-SEM). Recently, there is an increased use of PLS-SEM

rather than CB-SEM due to both theoretical and methodological reasons (Hair et al., 2012).Partial least square modeling is used to tackle many multi equation econometric models. Since PLS also reflects the sum of the diagonal in the covariance matrix, it is also suited for prediction. Basically a path model is a diagram that connects variables/constructs based on theory and logic to visually display the hypothesis that will be tested. Structural 
equation models are based on an analysis of correlation or covariance. PLS-SEM is more preferable than CB-SEM in case of small samples and when the focus is on prediction and theory development. With respect to methodological reasons,CB-SEM models require larger sample size and normal data for better goodness of fit indices in comparison with PLS-SEM.

\section{Results and Discussion}

In PLS SEM, the significance of factor loadings are assessed by the bootstrapping procedure with minimum samples of 5000 and the number of cases equivalent to sample size $(n=50)$. Bootstrapping is a non-parametric procedure which can be applied to test whether coefficients such as outer weights, outer loadings and path coefficients are significant by estimating standard errors for the estimates. In bootstrapping, the subsamples are created with observations randomly drawn from the original data set (with replacement).

Through the process of bootstrapping, reflective and formative indicators which were not significantly loading with their respective loadings or not meeting the criteria were removed from the model. For the reflective indicators, outer loading relevance testing is carried out based on the following criteria. If the outer loading is less than 0.40 , the reflective indicator is deleted. If the outer loading is less than 0.40 but greater than 0.40 , then the impact of indicator deletion on AVE and composite reliability is analyzed. If the deletion increases the measures above the threshold, then the reflective indicator is deleted. If the measures already meets the threshold, then the reflective indicator is retained. If the outer loading is greater than 0.70 , then the reflective indicator is retained. The reflective indicators of dividend yield (DIVYIELD), LNTA, LNSA and EG were removed from their respective constructs.

\subsection{Validity Assessment of Reflective Measurement Models}

The PLS SEM algorithm converged. The assessment of reflective measurement model is done through indicator reliability, internal consistency reliability, convergent liability and discriminant validity.

It is required that at least 50 per cent of each indicator's variance must be accounted for by the underlying construct.The indicator reliabilities for reflective measures are analyzed by examining the outer loadings. Indicator reliability is also known as indicator communality. Reflective indicators of $\mathrm{E} / \mathrm{P}$ for latent construct profitability, ROE for profitability and $\mathrm{WC} / \mathrm{TA}$ are found to be statistically significant. Loadings of value one indicate that the latent construct had only one reflective indicator. For example the only reflective indicator for the latent construct RISK is beta. The indicator reliability loading of E/P and WC/TA were above 0.70. For the latent construct profitability, E/P indicator has a higher loading than ROE. 
Table 5. Outer loadings of indicator reliabilities

\begin{tabular}{llll}
\hline & $\begin{array}{l}\text { Loadings for } \\
\text { Originals }\end{array}$ & Sample Mean & P Values \\
\hline BETA <- RISK & 1 & 1 & \\
CAPEX/TA <- INVESTDECI & 0.488 & 0.465 & 0.28 \\
DPO <- DIVPO & 1 & 1 & \\
E/P <- PROFITABILITY & 0.809 & 0.658 & 0.002 \\
LEV <- CAPITAL & & & \\
STRUCTURE & 1 & 1 & \\
LNME <- FIRMSIZE & 1 & 1 & 0.002 \\
ROE <- PROFITABILITY & 0.602 & 0.707 & \\
SG <- GROWTH & 1 & 1 & 0.017 \\
WC/TA <- INVESTDECI & 0.889 & 0.728 & \\
\hline
\end{tabular}

The internal consistency reliability of reflective measures is analyzed through composite reliability and Cronbach's alpha.

Table 6. Composite Reliability

\begin{tabular}{llr}
\hline & & \multicolumn{1}{l}{ P } \\
& Values & Values \\
\hline CAPITAL & & \\
STRUCTURE & 1 & \\
DIVPO & 1 & \\
FIRMSIZE & 1 & 0.002 \\
GROWTH & 1 & 0 \\
INVESTDECI & 0.661 & \\
PROFITABILITY & 0.67 & \\
RISK & 1 & \\
\hline
\end{tabular}

Composite reliability values of greater than 0.6 are generally acceptable. The $p$ values are statistically significant for the latent construct of INVESTDECI and PROFITABILITY. The reflective indicators of INVESTDECI (Investment Decisions) are CAPEX/TA (ratio of capital expenditure to total assets) and WC/TA (ratio of working capital to total assets). The reflective measures of PROFITABILITY are the ratio of earnings to price and return on equity. All the reflective measures have composite reliability. It has to be noted that other than the above discussed constructs, all the rest have value one since they are represented by only one reflective measure.

The Cronbach's alpha measure for the majority of the construct was above 0.7. The Cronbach's Alpha can be considered as the lower bound and the composite reliability as the upper bound of the true internal consistency reliability. 
Table 7. Average Variance Extracted (AVE)

\begin{tabular}{lrrrr}
\hline & $\begin{array}{l}\text { Original } \\
\text { Sample }\end{array}$ & \multicolumn{2}{c}{$\begin{array}{l}\text { Sample } \\
\text { Mean }\end{array}$} & $\begin{array}{l}\text { P } \\
\text { Values }\end{array}$ \\
\hline CAPITAL & & & & \\
STRUCTURE & 1 & 1 & \\
DIVPO & 1 & 1 & \\
FIRMSIZE & 1 & 1 & \\
GROWTH & 1 & 1 & 0 \\
INVESTDECI & 0.514 & 0.543 & 0 \\
PROFITABILITY & 0.509 & 0.519 & 0 \\
RISK & 1 & & \\
\hline
\end{tabular}

The average variance extracted (AVE) is the measure of convergent validity. AVE is the grand mean value of the squared loadings of all indicators associated with the construct. Each construct should account for atleast 50 per cent of the assigned indicators' variance. It is also referred to as construct communality. All the construct satisfy the convergent validity criterion.

Discriminant Validity

Discriminant validity is tested by means of assessment like Fornell Larcker, Cross loadings and the Heterotrait -monotrait ratio (HTMT)

Table 8. Fornell Larcker Measure

\begin{tabular}{|c|c|c|c|c|c|c|}
\hline & $\begin{array}{l}\text { CAPITAL } \\
\text { STRUCTURE }\end{array}$ & DIVPO & FIRMSIZE & GROWTH & INVESTDECI & PROFITABILITY \\
\hline \multicolumn{7}{|l|}{ CAPITAL } \\
\hline STRUCTURE & 1 & & & & & \\
\hline DIVPO & -0.198 & 1 & & & & \\
\hline FIRMSIZE & 0.053 & 0.081 & 1 & & & \\
\hline GROWTH & 0.041 & -0.313 & -0.131 & 1 & & \\
\hline INVESTDECI & -0.462 & -0.128 & 0.063 & 0.187 & 0.717 & \\
\hline PROFITABILITY & -0.068 & 0.148 & 0.017 & -0.53 & -0.164 & 0.713 \\
\hline RISK & -0.251 & 0.325 & 0.319 & -0.111 & 0.033 & -0.019 \\
\hline VALUE CREATION & -0.404 & 0.159 & -0.259 & -0.096 & 0.146 & 0.107 \\
\hline
\end{tabular}

The Fornell Larcker criterion suggests that the square root of AVE must be greater than the correlation of the construct with all other constructs including the formative measures in the structural model. This criterion is satisfied in this case. 


\section{Ml Macrothink}

Asian Journal of Finance \& Accounting

ISSN 1946-052X

2015, Vol. 7, No. 1

Table 9. Cross loadings

\begin{tabular}{lllllllll}
\hline & CAPITAL STRUCTURE & DIVPO & FIRMSIZE & GROWTH & INVESTDECI & PROFITABILITY & RISK & VALUE CREATION \\
\hline BETA & -0.251 & 0.325 & 0.319 & -0.111 & 0.033 & -0.019 & $\mathbf{1}$ & 0.145 \\
CAPEX/TA & -0.438 & 0.145 & 0.107 & 0.088 & $\mathbf{0 . 4 8 8}$ & 0.003 & 0.308 & 0.023 \\
DPO & -0.198 & $\mathbf{1}$ & 0.081 & -0.313 & -0.128 & 0.148 & 0.325 & 0.159 \\
E t / BE (t-1) & -0.187 & 0.045 & -0.297 & -0.023 & 0.162 & 0.137 & -0.013 & $\mathbf{0 . 6 4 9}$ \\
E/P & 0.054 & 0.158 & -0.039 & -0.428 & -0.2 & $\mathbf{0 . 8 0 9}$ & 0.001 & 0.099 \\
LEV & $\mathbf{1}$ & -0.198 & 0.053 & 0.041 & -0.462 & -0.068 & -0.251 & -0.404 \\
LNME & 0.053 & 0.081 & $\mathbf{1}$ & -0.131 & 0.063 & 0.017 & 0.319 & -0.259 \\
ROE & -0.19 & 0.037 & 0.083 & -0.32 & -0.008 & $\mathbf{0 . 6 0 2}$ & -0.034 & 0.049 \\
Return & -0.384 & 0.174 & -0.107 & -0.108 & 0.065 & 0.034 & 0.2 & $\mathbf{0 . 8 0 5}$ \\
SG & 0.041 & -0.313 & -0.131 & $\mathbf{1}$ & 0.187 & -0.53 & -0.111 & -0.096 \\
WC/TA & -0.298 & -0.223 & 0.016 & 0.167 & $\mathbf{0 . 8 8 9}$ & -0.19 & -0.124 & 0.155 \\
\hline
\end{tabular}

According to cross loading criteria, each indicator must load highest on the construct on which it is the indicator measure both in terms of reflective and formative measures.

Table 10. Discriminant Validity Assessment through Heterotrait -monotrait ratio (HTMT)

\begin{tabular}{lccccccc}
\hline & CAPITAL STRUCTURE & DIVPO & FIRMSIZE & GROWTH & INVESTDECI & PROFITABILITY & RISK \\
\hline CAPITAL STRUCTURE & & & & & & & \\
DIVPO & -0.198 & & & & & & \\
FIRMSIZE & 0.053 & 0.081 & & & & & \\
GROWTH & 0.041 & -0.313 & -0.131 & & & & \\
INVESTDECI & -2.013 & -0.212 & 0.337 & 0.698 & & & \\
PROFITABILITY & -0.504 & 0.722 & 0.161 & -2.778 & -2.557 & \\
RISK & -0.251 & 0.325 & 0.319 & -0.111 & 0.501 & -0.122 \\
\hline
\end{tabular}

HTMT is the average heterotrait -heteromethod correlations relative to the average monotrait -heteromethod correlations. Monotrait -heteromethod correlations represent correlations of indicators measuring the same construct.Heterotrait -heteromethod correlations are correlations of indicators across constructs measuring different phenomena. HTMT values close to 1 indicate lack of discriminant validity. The threshold value is considered close to 0.85 . The constructs in the study satisfy the discriminant validity assessment on the basis of HTMT.

\subsection{Validity Assessment of Formative Measurement Models}

The validity assessment of formative measurement models consists of assessingthe collinearity issues and assessment of significance and relevance of the formative indicators. Collinearity issues occurs when two or more indicators of a construct are highly correlated. Collinearity assessment is done through the analysis of VIF. If there are no critical levels of collinearity ( ie VIF $<5$ ), then the analysis enters the next stage. 
Table 11. VIF Values

\begin{tabular}{lc}
\hline \multicolumn{1}{c}{ VIF } \\
\hline BETA & 1.000 \\
CAPEX/TA & 1.001 \\
DPO & 1.000 \\
E t / BE (t-1) & 1.005 \\
E/P & 1.000 \\
LEV & 1.000 \\
LNME & 1.000 \\
ROE & 1.000 \\
Return & 1.005 \\
SG & 1.000 \\
WC/TA & 1.001 \\
\hline
\end{tabular}

The table shows that all VIF values are less than 5 .

The next stage consists of assessing the relevance of the formative indicators in the following manner. The outer weight is assessed to be significant or not. If the outer weight is significant, then the operation is continued with the interpretation of the outer weight's absolute and relative size. If the outer weight is not significant then the formative indicator's outer loading is analyzed. If the outer loading is less than 0.5 , then the significance of the formative indicator's outer loading is tested. If the outer loading is less than 0.5 and not significant, then the formative indicator is deleted. If the outer loading is less than 0.5 but is significant, then the removal of the indicator may be considered. If the outer loading is greater than 0.5 , then the indicator is retained even if it is not significant. The processing resulted in the removal of the formative indicator variable $\mathrm{MV} / \mathrm{BV}$. 


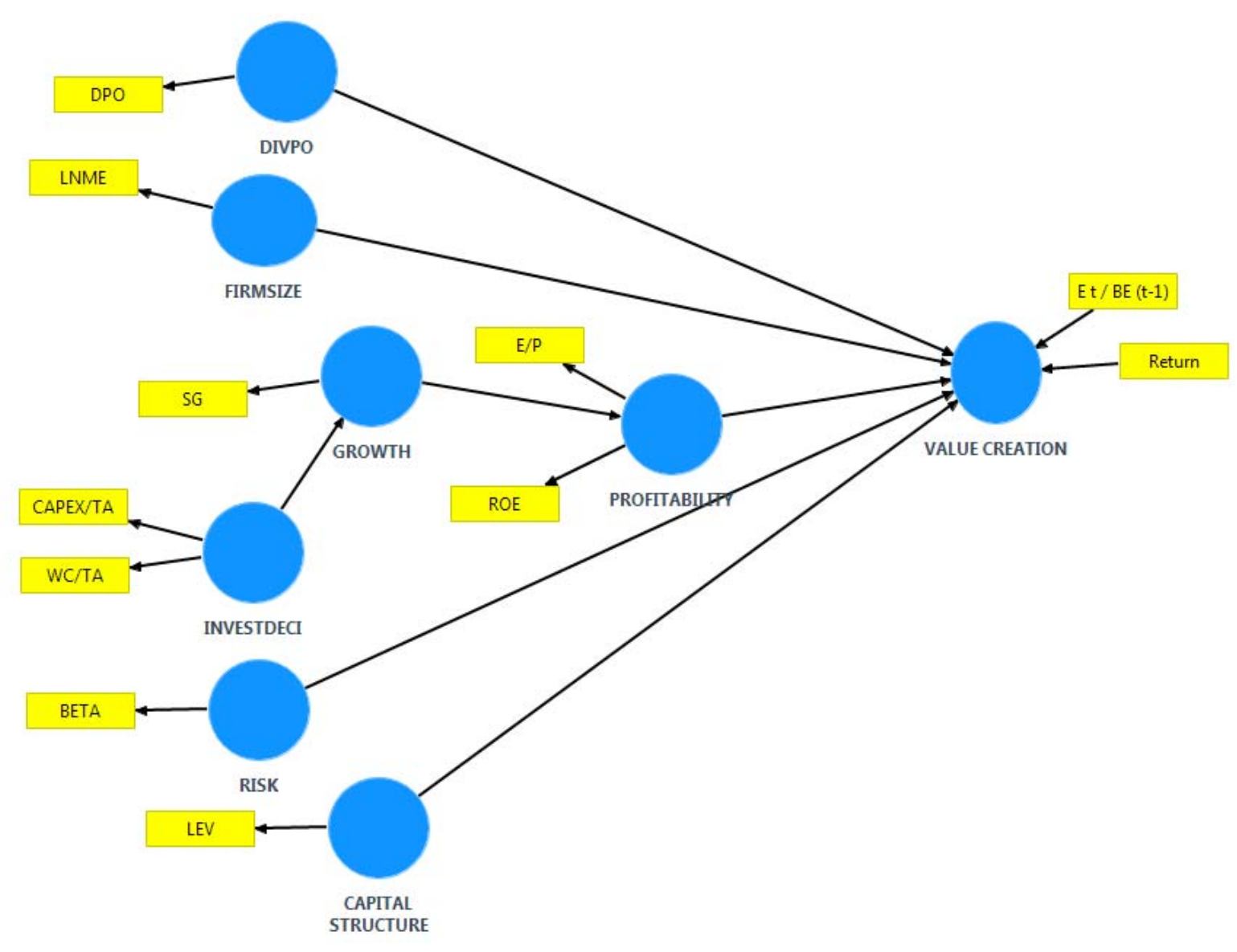

Figure 2. The final path diagram for value creation model

\subsection{Assessment of the Structural Model}

The assessment of the structural model consists of five steps.Firstly the structural model is assessed for collinearity issues. The VIF values are found to be less than 5. Hence structurally the model has no collinearity issues. The second step consists of assessing the significance and relevance of the structural model relationships. This process involves testing the significance and relevance of path coefficients. The path coefficients vary between -1 to +1 . The type of effects is divided into direct effect, indirect effect and total effect. The third step involves determination of coefficient of determination $\mathrm{R}$ Square. It is a measure of the model's predictive accuracy. The fourth step involves measurement of effect sizes by means of F Square. The fifth step involves estimation of $q$ square value to find the predictive relevance through Blindfolding. 
Table 12. Path Coefficients

\begin{tabular}{lrrrr}
\hline & Original Sample & Sample Mean & T Statistics & P Values \\
\hline CAPITAL STRUCTURE -> VALUE & & & & \\
CREATION & -0.337 & -0.310 & 2.195 & 0.029 \\
DIVPO -> VALUE CREATION & 0.060 & 0.058 & 0.371 & 0.711 \\
FIRMSIZE -> VALUE CREATION & -0.291 & -0.257 & 1.166 & 0.244 \\
GROWTH -> PROFITABILITY & -0.530 & -0.633 & 3.185 & 0.002 \\
INVESTDECI -> GROWTH & 0.187 & 0.245 & 1.194 & 0.233 \\
PROFITABILITY -> VALUE & & & & 0.456 \\
CREATION & 0.083 & 0.066 & 0.747 & 0.312 \\
RISK -> VALUE CREATION & 0.136 & 0.136 & 1.012 & \\
\hline
\end{tabular}

Capital structure variable of leverage is negatively related to value creation. The path coefficient is -0.337 for capital structure with statistical significance at $5 \%$ level of significance. Hence it can be assumed that higher the leverage for the firm, lesser will be the value creation for the firm. This result signifies that with respect to stock market valuation, investors are skeptical about whether firms with high leverage would create value. Firm size is negatively related to value creation. The path coefficient has a value of -0.291 but without statistical significance. Growth is negatively related to profitability with statistical significance. Investment decisions are positively related to growth. Hence firms which focus more on investment decisions like capital expenditures and working capital tend to create more value for the firm. Profitable firms tend to create more value for firms. Riskier the firm, higher the value creation. The results are not statistically significant.

Table 13. R Square

\begin{tabular}{ll}
\hline & R Square \\
\hline GROWTH & 0.035 \\
PROFITABILITY & 0.281 \\
VALUE CREATION & 0.250 \\
\hline
\end{tabular}

$\mathrm{R}$ Square is a measure of the model's predictive accuracy. It represents the amount of variance in the endogenous constructs explained by all of the exogenous constructs linked to it. The R Square value for value creation is 0.25 . Thus all the exogenous variables accounts for 25 per cent of variation in the endogenous construct value creation.

F Square measures the size effects. It assesses how strongly one exogenous construct contributes to explaining a certain endogenous construct in terms of $\mathrm{R}$ square. Growth to Profitability construct have strong effect and rest of the constructs has weak effects.

Blindfolding is an iterative procedure in which different parts of data matrix are omitted. The estimates based on the reduced datasets are used to predict the omitted parts. The prediction error is used as an indicator of predictive relevance. 
Table 14. Results of Blind Folding

\begin{tabular}{lrrr}
\hline & SSO & SSE & 1-SSE/SSO \\
\hline CAPITAL & & & \\
STRUCTURE & 50 & 50 & \\
DIVPO & 50 & 50 & \\
FIRMSIZE & 50 & 50 & \\
GROWTH & 50 & 50.186 & -0.004 \\
INVESTDECI & 100 & 100 & \\
PROFITABILITY & 100 & 91.426 & 0.086 \\
RISK & 50 & 50 & \\
VALUE & & & \\
CREATION & 100 & 97.732 & 0.023 \\
\hline
\end{tabular}

The q2 square value as given in the last column signify weak effect.

\section{Conclusion}

This paper proposes a theoretical model for value creation. Value creation is analyzed through path diagram through PLS SEM algorithm. Value creation for a firm is a function of its capital structure, investment decisions, size, growth, profitability and risk measures. The study finds that leverage is inversely related to value creation.Investors are skeptical about whether firms with high leverage would create value. Firm size is negatively related to value creation.

\section{References}

Amihud, Y. (2002). Illiquidity and stock returns: cross-section and time-series effects. Journal of Financial Markets, 5(1), 31-56. http://dx.doi.org/10.1016/S1386-4181(01)00024-6

Banz, R.W. (1981). The relationship between return and market value of common stocks. Journal of Financial Economics, 9, 3-18. http://dx.doi.org/10.1016/0304-405X(81)90018-0

Basu, S. (1983). The relationship between earnings yield, market value, and return for NYSE common stocks: Further evidence. Journal of Financial Economics, 12, 129-156. http://dx.doi.org/10.1016/0304-405X(83)90031-4

Bhandari, \& Laxmi, C. (1988). Debt/Equity ratio and expected common stock returns: Empirical evidence. Journal of Finance, 43, 507-528. http://dx.doi.org/10.1111/j.1540-6261.1988.tb03952.x

Bhattacharya, S. (1979). Imperfect information, dividend policy and "the bird in the hand" fallacy. Bell Journal of Economics, 10, 259-270. http://dx.doi.org/10.2307/3003330

Black, F. (1972). Capital market equilibrium with restricted borrowing. Journal of Business, 45, 444-455. http://dx.doi.org/10.1086/295472 
Boyer, M., \& Didier, F. (2007). Common and fundamental factors in stock returns of Canadian oil and gas companies. Energy Economics, 29(3), 428-453. http://dx.doi.org/10.1016/j.eneco.2005.12.003

Caby, J., Clerc, G., \& Koch, J. (1996). Strategic et finance: le processus de creation de vaieur. Revue Franpalse de Geslion, 108, 49-56.

Chan, L. K., Yasushi, H., \& Josef, L. (1991). Fundamentals and stock returns in Japan. Journal of Finance, 46, 1739-1789. http://dx.doi.org/10.1111/j.1540-6261.1991.tb04642.x

DeBodinat,H.(1978). Strategie et polique financiere. La Revue Banque, 374,750-756. Retrieved from http://www.groupeiscae.ma/pdf/Listes des thèses et des mémoires/Les publications de l'ISCAE/REVUE GESTION ET SOCIETE/Revue G\&S de $\mathrm{n}^{\circ} 1$ au $\mathrm{n}^{\circ} 16 /$ REVUE N¹6.1990.pdf

Degos,J.(1988). Evaluation des socieies el de lews litres. Vuibert. Retrieved from http://197.14.51.10:81/...Petit\%20br\%C3\%A9viaire\%20des\%20id\%C3\%A9es\%20re\%C3\% A 7 ues $\% 20$ en $\%$

Fama, E. F. (1976). Foundations of Finance. New York: Basic Books.

Fama, E.,\& French, K. (1995). Size and Book to Market factors in earnings and returns. The Journal of Finance, 50, 131-155. http://dx.doi.org/10.1111/j.1540-6261.1995.tb05169.x

Fama, E., \& French, R. (1992). The cross section of expected stock returns. The Journal of Finance, 47(2), 427-465. http://dx.doi.org/10.1111/j.1540-6261.1992.tb04398.x

Fruhan. (1984). How fast should your company grow? Harvard Business Review, 62, 84-93. Retrieved from http://web.a.ebscohost.com/ehost/detail/detail?vid=17\&sid=eaba2666-a83c-432a-925f-32c39 1b146b7\%40sessionmgr4005\&hid=4101\&bdata $=$ JnNpdGU9ZWhvc3QtbG12ZQ\%3d\%3d

Gamba, A., \& Triantis, A. (2008). The Value of financial flexibility. Journal of Finance, 63(5), 2263-2296. http://dx.doi.org/10.1111/j.1540-6261.2008.01397.x

Hair J F, C M Ringle, and M Sarstedt (2011). PLS SEM.Indeed a Silver Bullet. Journal of Marketing, Theory \& Practice, 19(2), 139-151. http://dx.doi.org/10.1016/j.lrp.2012.09.008

Hair, J F, M Sarstedt, T Pieper, C M Ringle, J A Mena (2012), The Use of Partial Least Squares Structural Equation Modelling in Strategic Management Research : A Review of Past Practices and Recommendations for Future Applications, Long Range Planning, 45(5/6),320-340.

Hair, J F,, Tomas Hult, Christian M Ringle, \& Marko Sarstedt. (2014). A Primer on Partial Least Squares, Structural Equation Modeling (PLS SEM).Thousand Oaks: Sage. http://dx.doi.org/10.1016/j.lrp.2012.09.008

Hair, J. F. Sarstedt, M. Pieper, T. M. \& Ringle, C. M. (2012). The use of partial least squares structural equation modeling in strategic management research: A review of past practices 
and recommendations for future applications. Long Range Planning, 45, Issue 5/6, pp. $320-340$

Hakansson, N. (1982). To pay or not to pay dividends? Journal of Finance, 37, 415-428. http://dx.doi.org/10.2307/2327345

Jacqueline, L., Garner, N., \& Richard, O. (2002).Determinants of corporate growth opportunities of emerging firms. Journal of Economics and Business, 54, 73-93. http://dx.doi.org/10.1016/S0148-6195(01)00056-X

James, M. (1973). Risk, return and equilibrium: Empirical tests. Journal of Political Economy, 81, 607-636. http://dx.doi.org/10.1086/260061

Leland, H., \& Pyle, D. (1977). Informational asymmetries, financial structure, and financial intermediation. Journal of Finance, 32, 371-388. http://dx.doi.org/10.2307/2326770

Lily, F., \&Joel, P. (2009). Media coverage and cross section of stock returns. Journal of Finance, 64(5), 2023-2052. http://dx.doi.org/10.1111/j.1540-6261.2009.01493.x

Michael, H., Duane, I., Michael, C., \& Donald, S.(2001). Entrepreneurial strategies for wealth creation. Strategic Management Journal, 22, 479-491. http://dx.doi.org/10.1002/smj.196

Miller, M.,\& Modigliani, F. (1961).Dividend policy, growth and the valuation of shares. Journal of Business, 34, 1031-1051.http://dx.doi.org/10.1086/294442

Miller, M., \& Rock, R. (1985). Dividend policy under asymmetric information. Journal of Finance, 40, 1031-1051. http://dx.doi.org/10.1111/j.1540-6261.1985.tb02362.x

Miller, M.,\& Scholes, M. (1978). Dividend and taxes. Journal of Political Economy, 90, 1118-1141. http://dx.doi.org/10.1086/261114

Myers, S. C. (1977).Determinants of corporate borrowing. Journal of Financial Economics, 5, 147-176. http://dx.doi.org/10.1016/0304-405X(77)90015-0

Pene, D. (1983). Modeles d'evaiuation des entreprises et modeles strategiques. Analyse Fmancierc, 54, 55-62.

Penman, S. H. (1991). An evaluation of accounting rate of return. Journal of Accounting, Auditing and Finance, 6, 233-255. Retrieved from http://web.a.ebscohost.com/ehost/detail/detail?vid=86\&sid=eaba2666-a83c-432a-925f-32c39 1b146b7\%40sessionmgr4005\&hid=4101\&bdata $=$ JnNpdGU9ZWhvc3QtbG12ZQ\%3d\%3d\#db $=$ bth $\& A N=7256368$

Rappaport, A. (1986). Linking competitive strategy and shareholder value analysis. The Journal of Business Strategy, 3, 58-67. Retrieved from http://web.a.ebscohost.com/ehost/detail/detail?vid=56\&sid=eaba2666-a83c-432a-925f-32c39 1b146b7\%40sessionmgr4005\&hid=4101\&bdata $=$ InNpdGU9ZWhvc3QtbG12ZQ\%3d\%3d\#db $=$ bth $\& A N=5691789$ 
Rappaport, A. (1987). Corporate performance standards and shareholder value. The Journal of Business Strategy, 4, 28-38. Retrieved from http://web.a.ebscohost.com/ehost/detail/detail?vid=58\&sid=eaba2666-a83c-432a-925f-32c39 1b146b7\%40sessionmgr4005\&hid=4101\&bdata $=$ JnNpdGU9ZWhvc3QtbG12ZQ\%3d\%3d\#db $=$ bth $\& A N=5689609$

Ringle, C. Wende, S. \& Will, A. (2005). SmartPLS, 2.0 (Beta), http://www.smartpls.de, Hamburg.

Rosenberg, B., Kenneth, R.,\& Ronald, L. (1985). Persuasive evidence of market inefficiency. Journal of Portfolio Management, 11, 9-17.http://dx.doi.org/10.3905/jpm.1985.409007

Ross, S. (1977). The determination of financial structure: the incentive signaling approach. Bell Journal of Economics, 8, 23-40. http://dx.doi.org/10.2307/3003485

Rozef, F. M. (1982). Growth, beta and agency costs as determinants of dividend payout ratios. $\begin{array}{llll}\text { Journal of } & \text { Financial 249-259. }\end{array}$ http://dx.doi.org/10.1111/j.1475-6803.1982.tb00299.x

Samy, N., \& Mohamed, G. (2002). The relationship between dividend policy, financial structure, profitability and firm value. Applied Financial Economics, 12, 843-849. http://dx.doi.org/10.1080/09603100110049457

Severine, C., Martin, H., \& Dusan, I.(2004). The determinants of stock returns in a small open economy. International Review of Economics and Finance, 13(2), 167-185. http://dx.doi.org/10.1016/j.iref.2003.07.001

Stattman, D. (1980). Book values and stock returns. The Chicago MBA: A Journal of Selected Papers, 4, 25-45.

Varaiya, N. (1987). The relationship between growth, profitability and firm value. Strategic Management Journal, 8, 487-497. http://dx.doi.org/10.1002/smj.4250080507 